\title{
A Comparative Analysis on SARS, MERS, and COVID-19
}

\section{SARS, MERS ve COVID-19 Üzerine Karşılaştırmalı Bir Analiz}

\author{
Atiksh Chandra1, DSathees B. Chandra² \\ 'Cypress Bay High School, Vista Park Blvd, Weston, FL, USA \\ 2Biomedical Sciences Program, College of Nursing and Health Sciences, Barry University, Miami Shores, USA
}

\begin{abstract}
The Severe Acute Respiratory Syndrome 2 (SARS-CoV-2/COVID-19) is on its way to become the pandemic of the century, if not already. As a coronavirus, it is known to cause severe respiratory illness, especially for those with compromised immune systems. The Severe Acute Respiratory Syndrome (SARS-CoV) and The Middle East Respiratory Syndrome (MERS-CoV) are the most notable of past coronaviruses infecting thousands in numerous countries. All three viruses are from a zoonotic origin predominantly from bats, one of the coronavirus's natural reservoir hosts. Therefore, the purpose of this article is to compare and contrast the attributes and features of all three coronaviruses. While SARS-CoV, MERSCoV, and COVID-19 share many viral similarities due to their similar classification, they are not as closely related genetically. COVID-19 shares about $79 \%$ of its genome with SARS-COV and only about $50 \%$ with MERS-CoV. One of the most notable genetic similarities between SARS-CoV and SARS-CoV-2 is their shared receptor protein, ACE2. Although all three viruses share the same dominant mode of human-to-human transmission, respiratory droplets, SARS-CoV-2 has a drastically higher infection rate than the other two. Aerosol and asymptotic transmission could be a leading factor for COVID-19's explosive infectivity. Currently, social distancing is the only effective preventive strategy to tackle COVID-19 until an effective vaccine is developed. Remdesivir, a nucleotide analogue drug, is showing positivity in reducing recovery time for patients. Convalescent plasma therapy treatment has also displayed promising recovery in some critically ill patients.
\end{abstract}

Keywords: SARS-CoV, MERS-CoV, COVID-19, Coronavirus, Vaccine, Social Distancing, Remdesivir

\section{Öz}

Şiddetli Akut Solunum Sendromu 2 (SARS-CoV-2 / COVID-19), şimdiden olmasa da yüzyılın pandemisi olma yolunda ilerliyor. Bir koronavirüs olarak, özellikle bağışıklık sistemi zayıflamış olanlar için ciddi solunum yolu hastalığına neden olduğu bilinmektedir. Şiddetli Akut Solunum Sendromu (SARS-CoV) ve Orta Doğu Solunum Sendromu (MERS-CoV), birçok ülkede binlerce kişiyi enfekte eden geçmiş koronavirüslerin en dikkate değer olanlarıdır. Üç virüs de zoonotik bir kökene sahip, ağırlıklı olarak koronavirüsün doğal rezervuar konaklarından biri olan yarasalardan gelmektedir. Bu nedenle, bu makalenin amacı, üç koronavirüsün de niteliklerini ve özelliklerini karşılaştırmaktır. SARS-CoV, MERS-CoV ve COVID-19, benzer sınıflandırmalarından dolayı birçok viral benzerliği paylaşırken, genetik olarak yakından ilişkili değillerdir. COVID-19, genomunun yaklaşık\% 79'unu SARS-COV ile ve sadece yaklaşık\% 50'sini MERS-CoV ile paylaşır. SARS-CoV ve SARS-CoV-2 arasındaki en önemli genetik benzerliklerden biri, paylaşılan reseptör proteinleri ACE2'dir. Her üç virüs de aynı baskın insandan insana bulaşma modunu paylaşsa da, solunum damlacıkları, SARS-CoV-2 diğer ikisinden çok daha yüksek bir enfeksiyon oranına sahiptir. Aerosol ve asimptotik iletim, COVID-19'un patlayıcı bulaşıcılığı için önde gelen bir faktör olabilir. Şu anda, sosyal mesafe, etkili bir aşı geliştirilinceye kadar COVID-19 ile mücadele için tek etkili önleyici stratejidir. Bir nükleotid analog ilaç olan Remdesivir, hastalar için iyileşme süresini kısaltmada pozitiflik gösteriyor. Nekahet plazma tedavisi tedavisi de bazı kritik hastalarda ümit verici bir iyileşme göstermiştir.

Anahtar Kelimeler: SARS-CoV, MERS-CoV, COVID-19, Koronavirüs, Aşı, Sosyal Uzaklaşma, Remdesivir

Corresponding (illetişim): Sathees B. Chandra, Biomedical Sciences Program (BMS), College of Nursing and Health Sciences, Barry University Miami Shores, FL 33161, USA

E-mail (E-posta): schandra@barry.edu

Received (Geliş Tarihi): 15.07.2020 Accepted (Kabul Tarihi): 13.09.2020 


\section{INTRODUCTION}

COVID-19 disease has been declared as a pandemic since the beginning of March 2020 by the World Health Organization (WHO). ${ }^{[1]}$ It was first reported in Wuhan, The People's Republic of China, in late December 2019. The causative virus for this disease was isolated and characterized in mid-January 2020. ${ }^{[2,3]}$ Based on its genetic relatedness to existing coronaviruses, WHO named this virus as severe acute respiratory syndrome coronavirus 2 (SARS-CoV-2). Since it first originated in 2019, it is also referred to as COVID-19 (Coronavirus disease 2019). This new coronavirus consists of about $30 \mathrm{~kb}$ positive sense single stranded ribonucleic acid (RNA) genome. It is known to infect a wide range of hosts including bats, humans and other mammals. SARS-CoV-2 is a Betacoronavirus, which is known to cause severe disease and outbreaks in humans. ${ }^{[3-5]}$

Coronaviruses, itself, are not unknown to humans. In November 2002, betacoronavirus Severe Acute Respiratory Syndrome (SARS or SARS-CoV) was the first coronavirus epidemic originating in Guangdong Province, Southern China harboring 8000 cases and 800 deaths. ${ }^{[6,7]}$ In June 2012, Middle East Respiratory Syndrome (MERS or MERS-CoV) was isolated in Jeddah, Saudi Arabia and grew to infect nearly 2,500 cases and 800 deaths predominately in middle eastern countries. ${ }^{[8]}$ SARS-CoV-2 surpasses them both as it has already killed more than 900,000 people worldwide and has infected over 28 million individuals in the last eight months. ${ }^{[9]}$ Evidently, SARS-CoV-2 is drastically more infectious and lethal in humans than any of its predecessors. Therefore, this article's aim is to compare and contrast the attributes and features of SARS-CoV-2, SARS-CoV, and MERS-CoV from a genetic and evolutionary perspective.

\section{ORIGINS/ HISTORY}

Within months of SARS-CoV's origins in the Guangdong Province, Southern China, SARS took the responsibility of being the first pandemic of the 21 st century. ${ }^{[6,7,70]}$ Other known human coronaviruses, such as HCoV- $229 \mathrm{E}$ (betacoronavirus 1) and HCoV- OC43 (betacoronavirus), are vaguely related to SARS as both viruses are primarily associated with the common cold and other minor illnesses. $[6,7]$ SARS-CoV has a zoonotic origin that can be traced back to a SARS like coronavirus present in animal species, specifically Himalayan palm civets and racoon dogs, that evolved through the species barrier to humans. This SARS-CoV-like virus was isolated in a live-animal market in Guangdong, China in October, 2003. ${ }^{[11]}$ From there, cases developed in China predominantly transmitting to healthcare workers. SARS- CoV spread to other east Asian countries such as Hong Kong, Taiwan, Vietnam, and Singapore eventually making its way to Toronto, Canada.. ${ }^{[12]}$ On July 5, 2003, the World Health Organization(WHO) announced that the global SARS outbreak was contained and on December 31, 2003, WHO received all reports describing 8,096 cases and 774 deaths in 29 countries and regions. ${ }^{[13]}$
MERS-CoV was first isolated in Saudi Arabia in 2012..$^{[14]}$ Unlike SARS-CoV, MERS predominantly extended to countries in the Middle East, Africa, and East Asia. Over 27 countries, MERSCoV had 2,494 cases and 858 deaths since September 2012. ${ }^{[1]}$ Although significantly fewer infections, the high case fatality rate of nearly $34.3 \%$ drastically surpasses the SARS-CoV case fatality rate of about 9.6\%. ${ }^{[15]}$ MERS was initially suspected of originating from bats as the genetic classification of MERS, as a linage $C$ betacoronavirus, closely associated with that of bat coronaviruses HKU4 and HKU5. ${ }^{[16,17]}$ NEOCoV, a coronavirus found in the South African Neoromicia capensis bats, was found to have $85 \%$ of its genome identical to that of the nucleotides of MERS-CoV, outlining a possible origin. ${ }^{[18]}$ Furthermore, bat coronavirus HKU4, found in the Guangdong Province, China, was discovered to have the same receptor protein, DPP4, despite their low nucleotide identities with MERS-COV (75.5\% to $81.2 \%) .{ }^{[16]}$ Regardless, no epidemiological links between human infections and bat coronaviruses were present, denying a bat origin of MERS. ${ }^{[17]}$ However, in 2013, the full-human genome of MERS-CoV was found in Dromedary camels in Saudi Arabia, along with 15\% of a camel derived coronavirus. Nucleotide Polymorphism signatures between the two strands revealed a possible cross-species transmission of MERS to humans. ${ }^{[19]}$ In 2014, MERS-CoV was isolated from Dromedary camels in Qatar, UAE furthering the evidence of a zoonotic origin. ${ }^{[20]}$ The genetic, epidemiological, and phenotypic connections between human infection and Dromedary camel infection prove a Dromedary origin to be much more likely. ${ }^{[17]}$ It is also accepted that a Dromedary coronavirus originated from bat coronaviruses through cross species transmission in the distant past. ${ }^{[21]}$ MERS has died down drastically since its peak in 2013, however, sporadic outbreaks have occurred, primarily in Saudi Arabia, from 2014 to 2019 . $^{[1]}$

SARS-CoV-2 is the most severe of human coronaviruses so far. Currently, there are about 28,523,343 cases and nearing one million deaths worldwide as the curve continues to increase exponentially. The United States is currently the epicenter of SARS-CoV-2 with more than 6,500,000 cases in and of itself. ${ }^{[9]}$ Unlike the SARS-CoV and MERS-CoV, SARSCoV-2 has a relatively low mortality rate of $3.5 \%$ (currently) with a significantly higher infection rate. COVID-19 was first reported in Wuhan, China in the Hubei province in December, 2019 as it is said to have originated from a local seafood market. ${ }^{[8,22]}$ Much like SARS-CoV and MERS-CoV, COVID-19, as a coronavirus, was traced back to its natural reservoir host bats. ${ }^{[23]}$ Specifically, bat betacoronavirus RaTG13, which was isolated in Yunnan territory, China, was found to have a 96.2\% genome similarity with SARS-COV-2. ${ }^{[22,24,25]}$ Although it was later proven that BatCoV RaTG13 could not have been the exact variant to cause SARS-CoV-2 in humans, a bat origin of COVID-19 is widely accepted. ${ }^{[26]}$ Furthermore, a strand of coronavirus found in Malayan Pangolins is found to have a similar amino acid identity to that of COVID-19. A particular spike gene native to that of SARS-CoV-2 may have partially 
been provided by this Pangolin variant. ${ }^{[27]}$ From an evolutionary perspective, SARS-CoV-2 originated in humans, by genetic mutation or recombination, from 1 of 3 theoretically plausible scenarios: (i) natural selection of a coronavirus in an animal host before a cross-species transmission (zoonotic transfer) (ii) zoonotic transfer followed by natural selection in humans (iii) natural selection of experimental viruses during laboratory passing. ${ }^{[28]}$ Ultimately, the most popular theory of SARS-CoV-2 origins is from bat and pangolin coronaviruses evolved by recombination to enter the human population as a zoonotic virus.

\section{Molecular Biology of SARS, SARS-COV-2 \& MERS}

Viruses, by definition, "are small obligate intracellular parasites which contain either an RNA or DNA genome surrounded by a protective, virus-coded protein coat." Viruses can be classified as a single-stranded or double stranded depending on genome structure. Often composed of basic proteins, the viral genome can be found inside a symmetric protein capsid or head. The nucleocapsid is composed of both the genome together with the nucleoprotein, a nucleic-acid associated protein. Capsids can also be described by one of three shapes: helical, polyhedral (Icosahedral), or complex. In enveloped viruses, such as coronaviruses, a lipid bilayer surrounds the nucleoplacid and an outer layer of virus-coded, glycosylated membrane proteins. Essentially, the nucleocapsid is equivalent to a virus without its envelope. If a virus does not have an envelope, a naked virus, the nucleocapsid describes the virus as a whole. A complete virus particle capable of transmitting its genome information to a host cell is known as a virion. ${ }^{[28]}$ Coronaviruses contain an enveloped, $5^{1}$-capped, single-stranded, positive-strand RNA molecule. As the largest of the known RNA viruses, they have a genome range of 25-32 kb (kilobases) much higher than any other RNA virus. [30] The coronavirus genus falls under the Coronaviridae family and the Nidovirales order. Coronaviruses can also be classified by four genera: Alphacoronavirus, Betacoronavirus, Gammacoronavirus, and Deltacoronavirus. These genera are divided by phylogenetic clustering but can easily be identified by their main reservoir host. Alpha- and Betacoronaviruses are known to infect mammalian species, Gammacoronaviruses are known to infect avian species, while Deltacoronaviruses are known to infect both. ${ }^{[31,32]}$

Although SARS-CoV, MERS-CoV, and SARS-CoV-2 are generally discussed together, they are not as closely related as they may seem at least from genetics perspective. The genome similarly between SARS-CoV-2 and SARS-CoV (about 79\%) is only slightly closer than that of SARS-CoV-2 and MERS-CoV (about $50 \%)$. RaTG13 seems to be the closest to SARS-CoV-2, in terms of genetic similarity, irrespective of being a bat coronavirus. [25] However, the genome lengths of the three viruses are not too different. SARS-CoV's full length genome has 29,751 base pairs, MERS-CoV's full length genome has 30,150 base pairs and SARS-CoV-2's full length genome has only 28,818. [33-35] Furthermore, each virus codes for a unique number of structural, accessory and non-structural proteins. The SARSCoV genome expresses 4 structural, 8 accessory, 16 nonstructural proteins to make up 28 proteins overall. ${ }^{[35]}$ SARSCoV-2 forms a total of 27 proteins composed of 4 structural, 8 accessory, and 15 non-structural proteins. ${ }^{[36]}$ MERS-CoV, despite having the largest genome length, only encodes 11 proteins: 4 structural, 2 accessory and 5 non-structural. ${ }^{[37]}$ As one may notice, each of the viruses have 4 structural proteins. These structural proteins, common to most coronaviruses, are the spike surface glycoprotein (S), the small envelope protein $(\mathrm{E})$, the matrix protein $(\mathrm{M})$, and the nucleocapsid protein $(\mathrm{N}) .^{[38]}$ Specifically, the spike surface glycoprotein is necessary for viral transmission as it plays a key part in the binding to receptor proteins on a host cell. ${ }^{[39]}$ Generally speaking, receptorbinding domains (RBD's) allow for the S-proteins of viruses to bind to host receptors. ${ }^{[38]}$ One of the main receptors of SARS$\mathrm{CoV}$ is known as angiotensin-converting enzyme 2 (ACE2). [38,40] SARS-CoV-2 shares this same human cell receptor, ACE2, while MERS-CoV uses dipeptidyl peptidase 4 (DPP4) as its main receptor. ${ }^{[36,41]}$ Not only does this illustrate a key similarity between SARS-CoV and SARS-CoV-2, but it may also explain one of the reasons behind SARS-CoV-2 and MERS-CoV's low genome similarity. Furthermore, a single nucleotide mutation on SARS-CoV-2's RBD, might have increased its already high pathogenicity. ${ }^{[42]}$

\section{Epidemiology of Covid-19 in contrast with SARS and MERS}

Epidemiology, roughly speaking, refers to the study of the factors that lead to the presence or abundance of a disease. ${ }^{[43]}$ Although Epidemiology concerns a broad spectrum of topics, this article will focus on patterns in disease spread, incubation periods, and possible symptoms. SARS-CoV, although first transmitted by animal-human contact, the most widespread route of transmission through the human community is by respiratory droplets from coughing and sneezing. A person who touches or inhales an infected area with residue may also be infected. ${ }^{[4]}$ Traces of SARS-CoV have also been found in tears, feces, urine of infected individuals. Furthermore, the presence of SARS-CoV in stool may suggest feco-oral transmission although it was not conclusively proven. ${ }^{[45]}$ In terms of international spread, SARS-CoV was also found, during the epidemic, to have transmitted through commercial airlines. ${ }^{[46]}$ A look into the demographics of patients around the world shows consistent patterns. Healthcare workers consisted of quite a large portion. Specifically, in Hong Kong, $22 \%$ of patients were healthcare workers while $41 \%$ of patients in Singapore had similar professions. Only $6 \%$ of Hong Kong SARS cases were under the age of 18 showing that infections in the younger population were relatively uncommon. Furthermore, nearly all of the infected youth population lived in close proximity to an adult with an infection. ${ }^{[47]}$ The median age of all SARS patients was reported to be under 50 years old. [48] 2-10 days is the general incubation period for SARS though an 6.4 days has been estimated by mathematical models. ${ }^{\text {[12] }}$ Major preceding symptoms of SARS include chills, fever, 
malaise, myalgia, and nonproductive cough while sore throat and rhinorrhea are less common. Respiratory deterioration, watery diarrhea and viral pneumonia were apparent. ${ }^{[49]}$

Unlike SARS-CoV, MERS-CoV, is more influenced by zoonotic transfer as humans only act as transient hosts for the virus. ${ }^{[50]}$ In humans, MERS-CoV has been detected predominantly in the lower respiratory tract, where the majority of DPP4 receptors are located, and in the upper respiratory tract, urine, stool, and blood of mildly and severely ill patients. ${ }^{[51]}$ In terms of viral transmission, large outbreaks of MERS-CoV were found in healthcare facilities. Specifically, MERS-CoV samples have been cultured from environmental objects such as bed sheets and radiograph devices, indicating possibilities of environmental transmission. ${ }^{[52]}$ Other possibilities of transmission include aerosol transmission, as air samples found in hospital rooms of MERS-CoV patients were found to have viral RNA, ${ }^{[53]}$ as well as fomite transmission, as MERS-CoV was proven to be relatively stable in environmental conditions. ${ }^{\left[{ }^{[4]}\right]}$ Environmental, aerosol, and fomite transmission of MERS-CoV are not definite modes of transmission as definite epidemiologic evidence is yet to be provided. Furthermore, the rate of secondary transmission in the household was only about 5\%. ${ }^{[55]}$ Patterns in the spread of MERS-CoV were also quite apparent specifically to the cases in South Korea (SK) and the Kingdom of Saudi Arabia (KSA), where the majority of all cases were found. [56] The average age of a MERS-CoV case in KSA and SK was 51 and 54 years respectively. Referring to transmission by healthcare facilities, most SK cases (about 94\%) were hospital related. However, in KSA, the majority (about $60 \%$ ) of the cases were of unknown origins. In terms of sex distribution, both countries had a slightly higher frequency of male cases. Overall, $65 \%$ of all MERS-CoV cases were in males rather than females. ${ }^{[57]}$ The mean incubation period for MERS-CoV is 6.4 days. Furthermore, evidence in South Korean cases suggests a correlation between shorter incubation period and higher risks for death specific to MERS-CoV. Compared to SARS-CoV, MERS-CoV, in the lower respiratory tract, has broader cell tropism and a higher replication rate. ${ }^{[58]}$ Cough was the most frequent symptom of MERS-CoV patients while fever was the most common symptom. Shortness of breath and diarrhea were also common among patients. More severe MERS-CoV symptoms include pneumonia and kidney failure..$^{[13,57]}$

Human to Human transmission by various means has led to SARS-CoV-2's worldwide spread. ${ }^{[59]}$ While SARS-CoV-2 may not be as severe as SARS-CoV in most cases, its infectivity is drastically higher. Like both SARS-CoV and MERS-CoV, SARS-CoV-2 is mainly transmitted via respiratory droplets coughing or sneezing ${ }^{[60]}$ One of the possible reasons for high infectivity is due to SARS-CoV-2 having the highest of its viral load, or quantity of a virus in a given fluid, in the nose and throat. ${ }^{[61]}$ Recent studies also propose a fecal-mouth route of transmission due to the detection of SARS-CoV-2 in stool. ${ }^{[62]}$ SARS-CoV-2 has also been isolated in the urine of patients. ${ }^{[63]}$ Transmission from stool and urine is yet to be conclusively proven and is in need of further study. In addition, SARS-
CoV-2's ability to remain infectious and viable on surfaces for days gives leeway to the possibility of surface transmission. Naturally, the surface in which the virus is found plays a role in viability. ${ }^{[64]}$ Moreover, airborne transmission of SARSCoV-2 has proven to be highly virulent and dominant in the spread of the virus. ${ }^{[65]}$ Nevertheless, the Achilles' heel of viral prevention comes from the asymptomatic transmission of COVID-19. Asymptomatic transmission essentially means the transmission of a virus while still in the incubation period or from an individual showing no symptoms of viral infection. Although weak, asymptomatic carriers of SARS-CoV-2 can still be infective. ${ }^{[6,67]}$ The incubation period of COVID-19 is 1-14 days, mostly 3-7 days. SARS-CoV-2 primarily targets the elderly and people with underlying diseases or compromised immune systems. The median age of all patients is between 47-59. ${ }^{[59]}$ Similar to MERS-CoV, the sex distribution of patients show a majority of male patients with the proportions of nearly $50 \%$ to $75 \%{ }^{[63]}$ Children, currently, tend to be the least affected by the virus possibility due to less viral contact and healthier immune systems. ${ }^{[68]}$ The clinical symptoms of SARS-CoV-2 are much like SARS-CoV and MERS-CoV. The most common include fever, cough, dyspnea, fatigue, myalgia, headaches, and sputum production. Sore throat, chest pain, conjunctival congestion, nausea, vomiting, diarrhea, rhinorrhea, and hemoptysis were present in some cases. ${ }^{[63]}$

\section{Treatment/Prevention Strategies}

Treatment for disease can come in many forms including vaccines, drugs, plasma therapy or prevention strategies. Specifically, vaccines are weakened versions of a pathogen or virus intended to create an immune response in the body without causing infection. A human's adaptive immune system will then produce an immunological memory and highly specific antibodies to prevent future infections. ${ }^{[69]}$ Drugs are substances that cause a biochemical or physiological change to a cell, tissue, organ, or organism. Currently, there is no vaccine or treatment that has the capability to fully mediate a SARS-CoV, MERS-CoV, or SARS-CoV-2 infection. Supportive care, or measures taken to reduce the effects of the disease symptoms rather than the disease itself, is the only currently implementable practice against any of these coronaviruses. Some examples of supportive care include supplemental oxygen and mechanical ventilation. ${ }^{[13]}$ Several drugs have a possibility in combating SARS-CoV and MERS-CoV. For a total of 66 compounds, 6 drugs can be active against SARS-CoV, 33 drugs can be active against MERS-CoV and 27 can be active against both. ${ }^{[70]}$ Ribavirin was a drug used in $90 \%$ of Hong Kong SARS-CoV cases. Although the drug has broad spectrum antiviral activity, it was later proven that it was unable to clear SARS-CoV from patients fully. Other drugs experimented with SARS-CoV include Lopinavir, Ritonavir and Corticosteroid. ${ }^{[71]}$ For MERS-CoV, the primary countermeasure drug to combat was a combination of Ribavirin and interferon-a2b. ${ }^{[72]}$ Some other drugs that have been moderately effective on both include: Chlorpromazine hydrochloride, Triflupromazine hydrochloride, Dasatinib, Imatinib mesylate, Gemcitabine 
hydrochloride, and Toremifene citrate. ${ }^{[70]}$ For COVID-19, much experimental data related to drug combat has not been completed yet.

Drugs used against SARS-CoV and MERS-CoV have potential against SARS-CoV-2. Additionally, clinical trials of Azithromycin, which are currently ongoing, may have potential against SARSCoV-2. ${ }^{[43]}$ Dexamethasone, a corticosteroid, has also been clinically tested in the United Kingdom and has had positive results in treating critically ill COVID-19 patients. ${ }^{[1]}$ Remdesivir, a nucleotide analogue drug, is currently the most anticipated treatment for Covid-19. Clinical trials of Remdesivir are ongoing across the world and is showing positivity in reducing recovery time for patients. ${ }^{[73,74]}$ EIDD-2801 is an orally bioavailable drug being clinically tested in the United Kingdom as it has shown a reduction in the replication of multiple coronaviruses in mice. [75] Furthermore, a treatment known as Convalescent plasma therapy is also being administered for severe Covid-19 cases in many countries. Convalescent plasma therapy essentially gives liquid plasma and antibodies from the donated blood of recovered SARS-CoV-2 patients to current patients. ${ }^{[76,77]}$ As of now, the U.S. food and Drug Administration, as well as many other countries, have authorized the use of Convalescent plasma therapy due to a lack of other viable alternatives. ${ }^{[78]}$ In terms of a vaccine, a large amount of information is still needed to develop a vaccine for any of the 3 coronaviruses. Although SARS-CoV and MERS-CoV infections are quite rare today, COVID-19 continues to infect by the thousands and could potentially evolve into new strains. The changing genetic make-up of SARS-CoV-2 by rapid evolution certainly is one of the main obstacles in developing vaccines in the near future.

Preventative strategies for SARS-CoV, MERS-CoV, and SARS$\mathrm{CoV}-2$ are mainly the same. The gist of these preventative measures is to simply reduce the number of infections in a given population. Most of these interventions involve proper hygiene and reduced social contact. "Social distancing", such as canceling mass gatherings and closing schools, was the main preventative strategy for SARS-CoV and MERS-CoV and is being implemented today for COVID-19. ${ }^{[79,80]}$ Evidence suggests that 1 meter of physical distancing between people at all times significantly reduces infectivity while 2 meters is more effective. Furthermore, the use of face masks reduces viral infectivity for the user and those around the user. N95 respirator masks reduce the risk of infection more so than that of disposable surgical makes or multilayered cotton masks. However, due to substantially increased numbers of infections throughout the world, only health care professionals have been asked to use this particular kind of mask. ${ }^{[81]}$ Additional strategies related to health and social distancing include isolating individuals travelling from affected regions for at least the length of incubation period, imposing travel restrictions from affected areas, maintaining hygiene such as rigorous hand washing with soap and use of gloves, spreading awareness of virus, and maintaining immunity by consumption of a nutritious diet and exercising at home. ${ }^{[82]}$
Another prevention strategy that has recently been brought to light during COVID-19 is known as Herd Immunity. Herd Immunity is based on acquired immunity or immunity at an individual level from either natural infection or vaccination. Essentially, herd immunity is individual immunity at a large population level. By cutting down the number of vulnerable people in a given population, the transmission of the pathogen significantly decreases. Herd immunity's primary goal is reaching the herd immunity threshold, or the point at which the vulnerable population falls under the lower limit necessary for successful transmission of the virus. ${ }^{[83]}$ While herd immunity seems adequate theoretically, there are many risks as the majority of the population needs to be infected for herd immunity to function. In the current COVID-19 pandemic, the United Kingdom initially proposed herd immunity but soon backed off as viral growth continued and resulted in higher death rate. Regardless, it appears that herd immunity may be a necessary strategy in tackling COVID-19. ${ }^{[84]}$

\section{CONCLUDING REMARKS}

There are several challenges and uncertainties related to fully understanding each of these viruses. The current pandemic has inspired an enormous amount of studies to uncover every feature of SARS-CoV-2 biology, epidemiology, and evolution. Innovative research coupled with urgency has, in a strikingly short amount of time, presented us with a plethora of structural and functional knowledge that may aid in the effective treatment of Covid-19 soon. Regardless, it is essential to produce a vaccine in record time as infections continue to grow by millions across the globe. The mumps vaccine, the fastest vaccine ever approved, took nearly 4 years to develop. In 2015, however, a ZIKA virus vaccine was ready for testing in an astonishing 7 months but was not approved as the epidemic died out before clinical trials were conducted. Currently, forecasters predict a fully ready COVID-19 vaccine for licensure to be available in early-mid 2021. While none of these predictions may be truly accurate, it does bring hope to the community. Many other aspects must be considered when identifying the best strategy for tackling this pandemic. Even once the effective vaccine is developed, producing it at a large scale across the globe will take a considerable amount of time. Economic challenges also arise during the pandemic. Adapting social distancing measures everywhere puts many businesses at a downfall financially. Not only does this bring down the economy, but also results in a reduction of jobs. In a country where economic growth is a priority, social distancing goes against the political goals and agendas of the nation. Striking a balance to protect both health and wealth is a necessary endeavor. Nevertheless, protecting the wellbeing of citizens should be the top priority for any nation. We should continue to enforce strict social distancing measures until necessary and provide access to funding research and clinical testing for a faster vaccine release are the solutions to the this current predicament. 


\section{ETHICAL DECLARATIONS}

\section{Status of Peer-review: Externally peer-reviewed.}

Conflict of Interest Statement: The authors have no conflicts of interest to declare.

Financial Disclosure: The authors declared that this study has received no financial support.

Author Contributions: All of the authors declare that they have all participated in the design, execution, and analysis of the paper, and that they have approved the final version

\section{REFERENCES}

1. Who.int [homepage on the Internet]. World Health Organization [updated 30 June 2020; cited 11 July 2020]. Available from www.who.int

2. Zhou $P$, Yang $X$, Wang, $X$ et al. A pneumonia outbreak associated with a new coronavirus of probable bat origin. Nature 2020; 579: 270-273.

3. Zhu N, Zhang D, Wang W et al. A Novel Coronavirus from Patients with Pneumonia in China, 2019. N Engl J Med 2020; 382:727-733

4. Ksiazek TG, Erdman D, Goldsmith CS, et al. A novel coronavirus associated with severe acute respiratory syndrome. N Engl J Med 2003; 348:19531966.

5. Jin $\mathrm{YH}, \mathrm{Cai} \mathrm{L}, \mathrm{Cheng} \mathrm{ZS}$, et al. A rapid advice guideline for the diagnosis and treatment of 2019 novel coronavirus (2019-nCoV) infected pneumonia (standard version). Mil Med Res. 2020;7(1):4.

6. Thomas G. Ksiazek, D.V.M., Ph.D., Dean Erdman, Dr.P.H., et al. A Novel Coronavirus Associated with Severe Acute Respiratory Syndrome. N Engl J Med 2003; 348:1953-66.

7. John Ziebuhr. Molecular biology of severe acute respiratory syndrome coronavirus. Curr Opin Microbiol 2004; 7:412-419.

8. Cascella M, Rajnik M, Cuomo A et al. Features, Evaluation and Treatment Coronavirus (COVID-19) [Updated 2020 Jul 4]. In: StatPearls [Internet]. Treasure Island (FL): StatPearls Publishing; 2020

9. Jhu.edu [homepage on the internet]. John Hopkins University of Medicine [Updated 11 July, 2020; cited 11 July 2020] Available from: https://coronavirus.jhu.edu/map.html.

10. Peiris JSM, Phil D, Yuen KY et al. The Severe Acute Respiratory Syndrome. N Engl J Med 2003; 349:2431-41.

11. Guan Y, Zheng BJ, He YQ, et al. Isolation and Characterization of Viruses Related to the SARS Coronavirus from Animals in Southern China. Science 2003; Vol. 302, Issue 5643,276-278

12. D S C Hui, M C H Chan, A K Wu, P C Ng. Severe acute respiratory syndrome (SARS): epidemiology and clinical features. Med J 2004; 80:373-381

13. Cdc.gov[homepage on the internet] Centers for Disease Control and Prevention.[Updated 30 June 2020; cited 11 july 2020] Available at www. cdc.gov

14.Zaki AM, Boheemen SV, Bestebroer TM et al. Isolation of a novel coronavirus from a man with pneumonia in Saudi Arabia. N Engl J Med. 2012;367(19):1814-1820.

15. www.medicalnewstoday.com [homepage in the internet] Medical News Today. [Updated 10 April 2020; cited 11 July 2020] Available at www. medicalnewstoday.com/articles/how-do-sars-and-mers-compare-withcovid-19

16. Luo CM, Wang N, Yang XL et al. Discovery of novel bat coronaviruses in South China that use the same receptor as Middle East respiratory syndrome coronavirus. JVirol 2018; 92: e00116-18.

17. Goldstein SA, Weiss SR. Origins and pathogenesis of Middle East respiratory syndrome-associated coronavirus: recent advances. F1000Res. 2017; 6:1628.

18. Victor Max Corman, Ndapewa Laudika Ithete, et al. Rooting the Phylogenetic Tree of Middle East Respiratory Syndrome Coronavirus by Characterization of a Conspecific Virus from an African Bat. J Virol 2014; 88 (19) 11297-11303.
19. Memish ZA, Cotten M, Meyer B, Watson SJ, Alsahafi AJ, et al. Human infection with MERS coronavirus after exposure to infected camels, Saudi Arabia, 2013. Emerg Infect Dis. 2014 Jun;20(6):1012-5.

20. Raj VS, Farag EA, Reusken CB, Lamers MM, et al. Isolation of MERS coronavirus from a dromedary camel, Qatar, 2014. Emerg Infect Dis. 2014 Aug;20(8):1339-42.

21. Banerjee A, Kulcsar K, Misra V, Frieman M, Mossman K. Bats and Coronaviruses. Viruses 2019; 11(1):41.

22. Zhou, P., Yang, X., Wang, X. et al. A pneumonia outbreak associated with a new coronavirus of probable bat origin. Nature 2020; 579, 270-273

23. LiW, Shi Z, Yu M, et al. Bats are natural reservoirs of SARS-like coronaviruses. Science 2005;310(5748):676-679.

24. Murahwa AT, Onywera H, Nindo F. SARS-CoV-2 Origins and Evolution: Insights from Coronaviruses Recombination and Phylogenetic Analysis, 07 July 2020, PREPRINT (Version 2) available at Research Square [+https:// doi.org/10.21203/rs.3.rs-30068/v2+]

25. Lu R, Zhao X, Li J et al. Genomic characterization and epidemiology of 2019 novel coronavirus: implications for virus origins and receptor binding. Lancet 2020; 395: 565-74

26. Paraskevis D, Kostaki EG, Magiorkinisa G et al. Full-genome evolutionary analysis of the novel coronavirus (2019-nCoV) rejects the hypothesis of emergence as a result of a recent recombination event. ELS ERG B S 2020; 79: 104212

27. Xiao K, Zhai J, Feng Y et al. Isolation and Characterization of 2019-nCoVlike Coronavirus from Malayan Pangolins. bioRxiv 2020; [PREPRINT] doi: https://doi.org/10.1101/2020.02.17.951335

28. Andersen, K.G., Rambaut, A., Lipkin, W.I. et al. The proximal origin of SARSCoV-2. Nat Med 2020; 26: 450-452.

29. Gelderblom HR. Structure and Classification of Viruses. In: Baron S, editor. Medical Microbiology. 4th edition. Galveston (TX): University of Texas Medical Branch at Galveston; 1996. Chapter 41.

30. Perlman, S., Netland, J. Coronaviruses post-SARS: update on replication and pathogenesis. Nat Rev Microbiol 2009; 7: 439-450.

31. Fang Li. Structure, Function, and Evolution of Coronavirus Spike Proteins. Ann Rev Virol 2016; 3:1, 237-261

32. Fehr AR, Perlman S. (2015) Coronaviruses: An Overview of Their Replication and Pathogenesis. In: Maier H., Bickerton E., Britton P. (eds) Coronaviruses. Methods in Molecular Biology, vol 1282. Humana Press, New York, NY

33. Kim JM, Chung YS, Jo HJ, Lee NJ, et al. Identification of Coronavirus Isolated from a Patient in Korea with COVID-19. Osong Public Health Res Perspect. 2020 Feb;11(1):3-7.

34. Chung YS, Kim JM, Man Kim H, Park KR, et al. Genetic Characterization of Middle East Respiratory Syndrome Coronavirus, South Korea, 2018. Emerg Infect Dis. 2019 May;25(5):958-962.

35. Satija N, Lal SK. The molecular biology of SARS coronavirus. Ann N Y Acad Sci. 2007 Apr; 1102(1):26-38.

36. Petrosillo N, Viceconte G, Ergonul O et al. COVID-19, SARS and MERS: are they closely related? Els Erg B S 2020; 26(6): 729-34

37. Kandeil A, Shehata MM, El Shesheny R, Gomaa MR, Ali MA, Kayali G. Complete Genome Sequence of Middle East Respiratory Syndrome Coronavirus Isolated from a Dromedary Camel in Egypt. Genome Announc. 2016 Apr 28;4(2):e00309-16.

38. Wu A, Peng Y, Huang B, et al. Genome Composition and Divergence of the Novel Coronavirus (2019-nCoV) Originating in China. Cell Host Microbe. 2020;27(3):325-328.

39. Li F. Structure, Function, and Evolution of Coronavirus Spike Proteins. Annu Rev Virol. 2016; 3(1):237-261.

40. Ge XY, Li JL, Yang XL, Chmura AA, et al. Isolation and characterization of a bat SARS-like coronavirus that uses the ACE2 receptor. Nature. 2013; 503(7477):535-8.

41. Wang, N., Shi, X., Jiang, L. et al. Structure of MERS-CoV spike receptorbinding domain complexed with human receptor DPP4. Cell Res 2013;23: 986-993.

42. Wan Y, Shang J, Graham R, et al. Receptor Recognition by the Novel Coronavirus from Wuhan: an Analysis Based on Decade-Long Structural Studies of SARS Coronavirus. J Virol. 2020; 94(7):e00127-20. 
43. Nidcd.nih.gov [homepage of the Internet]. National Institute of Deafness and Other Communication Disorders [Updated 13 Sep 2011, cited 11 July 2020]. Available from: https://www.nidcd.nih.gov/health/statistics/whatepidemiology

44. Seto WH, Tsang D, Yung RW, et al. Effectiveness of precautions against droplets and contact in prevention of nosocomial transmission of severe acute respiratory syndrome (SARS). Lancet. 2003; 361(9368):1519-20.

45. Cheng VCC, Lau SKP, Woo PCY et al. Severe Acute Respiratory Syndrome Coronavirus as an Agent of Emerging and Reemerging Infection. Clin Microbiol Rev 2007. 20 (4) 660-694

46. Olsen SJ, Chang HL, Cheung TY et al.Transmission of the Severe Acute Respiratory Syndrome on Aircraft N Engl J Med 2003; 349:2416-2422.

47. Zhong NS, Wong GW. Epidemiology of severe acute respiratory syndrome (SARS): adults and children. Paediatr Respir Rev. 2004; 5(4):270-4.

48. Wong GWK, Li AM, Ng PC et al. Severe acute respiratory syndrome in children. Pediatr Pulmonol. 2003;36(4):261-6.

49. Cheng VC, Lau SK, Woo PC, Yuen KY. Severe acute respiratory syndrome coronavirus as an agent of emerging and reemerging infection. Clin Microbiol Rev. 2007 ;20(4):660-94.

50. Dudas G, Carvalho LM, Rambaut A et al. MERS-CoV spillover at the camelhuman interface. eLife 2018;7:e31257

51. Killerby ME, Biggs HM, Midgley CM, Gerber SI, Watson JT. Middle East Respiratory Syndrome Coronavirus Transmission. Emerg Infect Dis. 2020;26(2):191-198.

52. Bin SY, Heo JY, Song MS, Lee J, et al. Environmental Contamination and Viral Shedding in MERS Patients During MERS-CoV Outbreak in South Korea. Clin Infect Dis. 2016;62(6):755-60.

53. Kim SH, Chang SY, Sung M, et al. Extensive Viable Middle East Respiratory Syndrome (MERS) Coronavirus Contamination in Air and Surrounding Environment in MERS Isolation Wards. Clin Infect Dis. 2016;63(3):363-9.

54. Doremalen NV, Bushmaker T, Munster VJ. Stability of Middle East respiratory syndrome coronavirus (MERS-CoV) under different environmental conditions. Euro Surveill 2013;18(38):pii=20590

55. Drosten C, Meyer B, Müller MA et al. Transmission of MERS-Coronavirus in Household Contacts. N Engl J Med 2014; 371:828-835

56. Liu S, Chan T-C, Chu Y-T, Wu JT-S, Geng X, Zhao N et al. Comparative Epidemiology of Human Infections with Middle East Respiratory Syndrome and Severe Acute Respiratory Syndrome Coronaviruses among Healthcare Personnel. PLoS ONE 2016; 11(3): e0149988.

57. Chen X, Chughtai AA, Dyda A et al. Comparative epidemiology of Middle East respiratory syndrome coronavirus (MERS-CoV) in Saudi Arabia and South Korea. Emerg Microbes Infect. 2017;6(6): e51.

58. Virlogeux V, Park M, Wu JT, Cowling BJ. Association between Severity of MERS-CoV Infection and Incubation Period. Emerg Infect Dis. 2016; 22(3):526-8.

59. Guo YR, Cao QD, Hong ZS, et al. The origin, transmission and clinical therapies on coronavirus disease 2019 (COVID-19) outbreak - an update on the status. Mil Med Res. 2020;7(1):11.

60. Li Q, Med M, Guan X et al. Early Transmission Dynamics in Wuhan, China, of Novel Coronavirus-Infected Pneumonia. N Engl J Med 2020; 382:1 1991207.

61. Zou L, Ruan F, Huang M, et al. SARS-CoV-2 Viral Load in Upper Respiratory Specimens of Infected Patients. N Engl J Med. 2020;382(12):1177-1179.

62. Amirian ES. Potential fecal transmission of SARS-CoV-2: Current evidence and implications for public health. Int J Infect Dis 2020; 95:363-70

63. Ge H, Wang X, Yuan X, Xiao G, Wang C, Deng T, Yuan Q, Xiao X. The epidemiology and clinical information about COVID-19. Eur J Clin Microbiol Infect Dis. 2020 Jun;39(6):1011-1019.

64. Doremalen NV, Bushmaker T, Morris DH, et al. Aerosol and Surface Stability of SARS-CoV-2 as Compared with SARS-CoV-1. N Engl J Med. 2020;382(16):1564-1567.

65. Zhang R, Li Y, Zhang AL et al. Identifying airborne transmission as the dominant route for the spread of COVID-19. P Natl A Sci Usa 2020, 117 (26) 14857-14863.

66. Gao M, Yang L, Chen X, Deng Y, Yang S, Xu H, Chen Z, Gao X. A study on infectivity of asymptomatic SARS-CoV-2 carriers. Respir Med. 2020;169:106026.
67. Bai Y, Yao L, Wei T, et al. Presumed Asymptomatic Carrier Transmission of COVID-19. JAMA. 2020;323(14):1406-1407.

68. Abduljalil JM, Abduljalil BM. Epidemiology, genome, and clinical features of the pandemic SARS-CoV-2: a recent view. New Microbes New Infect. 2020; 35:100672.

69. Federman RS. Understanding vaccines: a public imperative. Yale J Biol Med. 2014;87(4):417-22.

70. Dyall J, Coleman CM, Hart BJ et al. Repurposing of Clinically Developed Drugs for Treatment of Middle East Respiratory Syndrome Coronavirus Infection. Antimicrob Agents Ch 2014; 58(8): 4885-4893.

71. Yu WC, Hui DSc, Chan-Yeung M. Antiviral Agents and Corticosteroids in the Treatment of Severe Acute Respiratory Syndrome (SARS). Thorax 2004; 59(8):643-645.

72. Khalid M, Al Rabiah F, Khan B et.al. Ribavirin and interferon- $a 2 b$ as primary and preventive treatment for Middle East respiratory syndrome coronavirus: a preliminary report of two cases. Antivir Ther. 2015;20(1):8791.

73. Saha A, Sharma AR, Bhattacharya M et al. Probable Molecular Mechanism of Remdesivir for the Treatment of COVID-19: Need to Know More. Arch Med Sci 2020; 51(6): 585-586

74. Frediansyah A, Nainu F, Dhama K et al. Remdesivir and its antiviral activity against COVID-19: A systematic review. Clin Epidemiol Glob Health doi: 10.1016/j.arcmed.2020.05.001

75. Sheahan TP, Sims AC, Zhou S et al. An orally bioavailable broad-spectrum antiviral inhibits SARS-CoV-2 in human airway epithelial cell cultures and multiple coronaviruses in mice. Sci Transl Med 2020; 12(541) doi: 10.1126/ scitransImed.abb5883

76. Yiğenoğlu TN, Hacıbekiroğlu T, Berber I et al. Convalescent plasma therapy in patients with COVID-19. J Clin Apheresis 2020; 35(4):367-373

77. Zhang L, Pang R, Xue $X$ et al. Anti-SARS-CoV-2 virus antibody levels in convalescent plasma of six donors who have recovered from COVID-19. Aging (Albany NY). 2020;12(8):6536-6542.

78. FDA.Gov [Homepage on the Internet] U.S. food and drug administration. [Updated 23 Aug 2020, cited 12 Sep 2020]; Available from: https://www. fda.gov/news-events/

79. Bell DM; World Health Organization Working Group on International and Community Transmission of SARS. Public health interventions and SARS spread, 2003. Emerg Infect Dis. 2004;10(11):1900-6.

80. Park SW, Jang HW, Choe YH, et al. Avoiding student infection during a Middle East respiratory syndrome (MERS) outbreak: a single medical school experience. Korean J Med Educ. 2016; 28(2):209-17.

81. Chu DK, Akl EA, Duda $S$ et al. Physical distancing, face masks, and eye protection to prevent person-to-person transmission of SARS-CoV-2 and COVID-19: a systematic review and meta-analysis. Lancet 2020; 395(10242): 1973-1987.

82. Srivastava N, Saxena SK. Prevention and Control Strategies for SARSCoV-2 Infection. In: Saxena S. (eds) Coronavirus Disease 2019 (COVID-19). Medical Virology: From Pathogenesis to Disease Control. Springer, Singapore; 2020. P127-40.

83. Randolph HE, Barreiro LB. Herd Immunity: Understanding COVID-19. Immunity. 2020;52(5):737-741.

84. Nationalgeographic.com. [Homepage on the Internet] National Geographic Society [updated 20 Mar 2020, cited 11 July 2020]; Available from: https://www.nationalgeographic.com 